\title{
1. 病態解明と診断基準策定のあゆみ
}

住友病院 松澤 佑次

世界の肥満基準BMI 30 以上の頻度が約 1/10 である我が国においても, 肥満に基づく糖尿病 や高血圧の頻度が欧米とほぼ同等であることか ら, 肥満対策が重要であることはいうまでもな い. 欧米の高度肥満を対象とした公衆衛生的な 対策が全く効果をもたらしていない現状の中で, 日本肥満学会では肥満の判定基準をBMI 25 に設 定して, その中で医学的な目的で瘦せるべき肥 満を抽出して「肥満症」という疾患と診断し, 医療として治療対策を行うという考え方を 2000 年のガイドラインによって提案した。肥満症の 診断基準としては, BMI 25 以上の肥満の中で, 肥満に基づく，言い換えれば，減量すれば改善 する健康障害を有する状態を肥満症と診断する 考え方である.また, 脂肪組織蓄積の量的過剩 よりも腹腔内の内臓脂肪の過剩蓄積が多くの疾 患発症に関連する事実が明らかになり, 内臓脂 肪型肥満を肥満症と診断するという基準も採用 しているが, 上記の健康障害の有無による肥満 症も大半は内臓脂肪型である。一方, 肥満症の 病態発症メカニズムについては, 1990 年代の後
半から，我が国が世界に先駆けて明らかにした アディポサイトカインの概念から多くの知見が 得られてきた. 内臓脂肪蓄積時に過剩に分泌さ れるFFA, TNF $\alpha, \mathrm{PAI}-1$ などが病態発症の要因 となり，また，我が国で発見されたアディポネ クチンという脂肪細胞由来の善玉蛋白の低下な どが, 肥満症の病態発症に大きく貢献すること が明らかにされてきた。ささらに，2000 年代の前 半からメタボリックシンドロームという内臓脂 肪蓄積を基盤にしたマルチプルリスク症候群が 注目されるようになり, 日本内科学会を含む 8 学会の横断的な委員会を開催し, その定義, 診 断基準を策定したのが 2005 年 4 月である. 本疾 患概念は, 内臓脂肪蓄積の基準值など肥満症の 概念と重なる部分も多いが, 肥満症が個々の健 康障害の改善がターゲットであるのに反し, 動 脈硬化予防がターゲットであるという点で異な る. 本講演では, 肥満症, メタボリックシンド ロームの診断の意義と分子メカニズムについて 述べる.

\section{2. メタボリックシンドロームの分子機構}

\section{東京医科歯科大学医学部附属病院糖尿病 - 内分泌 - 代謝内科 小川 佳宏}

メタボリックシンドロームの概念は, 内臓脂 肪型肥満を背景として耐糖能異常, 脂質異常症, 血圧上昇などの病態が並行して進展し, 糖尿病, 高血圧症, 非アルコール性脂肪肝炎 (non-alcoholic steatohepatitis : NASH), 慢性腎藏病, 動脈硬化

各演者の略歴は 134 136 頁に記載
症などの生活習慣病を発症するという流れを指 摘したものである。多くの生活習慣病は過栄養 や運動不足などの代謝ストレスにより発症する と考えられているが，これらの疾患の発症時期 は微生物感染のように明確ではなく, 臨床症状 が顕性化するまでに年余の時間を要することも 稀ではない。このため, どのようにしてメタボ 